\title{
The Use of Euphemism in Karonese Language Langkat
}

\author{
Agustina Br Surbakti ${ }^{1} \&$ Yeni Winda Tresiany ${ }^{2}$ \\ ${ }^{1,2}$ English Applied Linguistics Study Program, Postgraduate School, State University of Medan, Indonesia
}

\begin{tabular}{l}
\hline \hline ARTICLE INFO \\
\hline \hline Article history: \\
Received Sep 26, 2018 \\
Revised Jan 02, 2018 \\
Accepted Jan 02, 2019 \\
\hline Keywords: \\
Euphemism, \\
Karonese Language Langkat, \\
Mathematics, \\
Equivalence \\
\hline Clonflict of Interest: \\
None
\end{tabular}

Funding:

\begin{abstract}
This research was conducted to identify the function of euphemism used in Karonese Laguage Langkat. This research applied qualitative descriptive approach. The qualitative data were taken from interview in karonese people at villange bahorok, langkat. The instrument for collecting the data through interview. The result of the analysis from interview the data taken from the respondents show that euphemism used in Karonese language divided in some categories such pronoun, adjective, verb, and noun. The use of Euphemism in Karonese language is not only for the words, but also in some phrases. In express the euphemism, karonese culture used Euphemism to communication. And the last one is karonese people usually use Euphemism to express the euphemism in situation or condition. The content of social values in the mourning tradition of karonese's culture has function to motivate, advice, amuse, and strengthen the condolences family. And in educational function that can be as the reflection for the people about the importance of this tradition for readers especially young generation.
\end{abstract}

None

Corresponding Author: Agustina Br. Surbakti, English Applied Linguistics Study Program, Postgraduate School, State University of Medan, Jl. Willem Iskandar Pasar V, Kenangan Baru, Percut Sei Tuan, Kabupaten Deli Serdang, Sumatera Utara - Kotak Pos No. 1589 - Medan 20221 Indonesia. Tel: 62-8137652-1300. E-mail: tina92578@gmail.com

Copyright $@$ Association of Language Teachers in Southeast Asia. All rights reserved

\section{INTRODUCTION}

\subsection{Background}

Language is part of culture and communication. Language is a unique human inheritance that plays important role in human's life, such as in thinking,communication, idea and negoitating with others. It plays a very important role in it to show the identity, the way to speak or communication, and culture is also included in part of human's life because there is a rule to manage of human's life in delivering ideas, communication, and doing negoitating that must be obeyed by certain people that run the culture in their environment's life. Language is the ability that humans have to communicative with other humans using signs such as words and movements. The purpose of language to can communication in society culture and which can be associated as a medium for delivering a massage or information. In indonesia has many ethnic groups and ethnicity. Each tribe has its own language, which maintained by the speaker. Especially in karonese has ethnic, namely karonese language. There are a possibility no appearance of the form and same word, but have different meanings. The difference meaning often gives rise to a difference between the perception and interpretation of the speaker with the listener. Here errors of perception and interpretation of the meaning of the word because the word agaist the possibility of having more than one meaning. Another cause is the use of euphemism, namely the use of the fine words as subtitle for the words that are considered to have meaning. 
Euphemisms are used when we talk about "taboo or sensitive subject", and therefore euphemistic language is "also the language of evasion, of hypocrisy, of prudery, and of deceit" (Holder 2002:vi). These roundabout expression are strongly related to politeness,"that which is polite is at least innofensive and at best pleasing to an audience, and that which is offensive is impolite" (Allan and Burridge 2006: 30). Euphemism is a word or phrase that replaces a taboo word or serves to avoid frightening or unpleasant subject. ( Victoria Fromkin,2003). Euphemism is a generally innocuous word expression used in place of one that may be found offensive or suggest something unpleasant. We use Euphemism everyday and probably do not know it. Euphemism are used to refer to taboo topics (such as wedding, ceremony and death) in polite way. The Purpose of Euphemism use has a large range from the merely innocent to evading responsibility for war crimes. Euphemisms are long standing cultural phenomenon in most languages. As social tools, euphemistic expressions are widely used in every level of society to meet certain communicative needs, show respect, humility, and politeness. These tools could make our speech more expressive and colorful since they adapt speech to different situations. Muna (2016) said that euphemisms are long standing cultural phenomenon in most languages. As social tools, euphemistic expressions are widely used in every level of society to meet certain communicative needs, show respect, humility, and politeness. These tools could make our speech more expressive and colorful since they adapt speech to different situations. The source of data will be taken from interview in people karonese at villange bahorok, langkat. In order to make the process of collecting data becomes easier, a table will be created to arrange the euphemism words. And in Linguistic politeness and culture in karonese society English, the theorical aspect politness which proposed by Brown and levinson (1987) was applied in this study. Negative face, in turn, involves distance and formality and defined as "the want of every "competent member" that his action be unimpeded by others" Brown and levinso 1987;61). This study was in the field of translation studies which linked with translating a karonese culture into English. Many karonese society is one of the Batak. They are Toba, karo, simalungun, pakpak,Angkola-mandailing -of north sumatra (singarimbun 1975).

\subsection{Reasearch Objectives}

Based on the problem Karonese Society, the purposes for this research are :

1) To analyze Euphemism expressions use in Karonese Language

2) Individual adaptation and adjustment to the changing global and social Environment is the key to Succes, to understand one's own cultural values and beliefs in order to be able to adapt to other cultures.

3) Can help the readers to know about the social value in mourning tradition and preserve mourning tradition from the modernization development and can be a reflection for the society as the moral lesson in life especially for young generation because of the minim lesson and minus realization about this tradition for this time.

\subsection{Research Questions}

In line with the purpose of the study, the research questions are:

1) What is the meaning and the function of euphemism used in karonese language langkat?

2) What are the social values in mourning tradition in karoneses culture?

3) Why did the Euphemism use in karonese languages langkat as the way they are?

\section{LITERATURE REVIEW}

\subsection{What is Taboo in Euphemish?}

The English word 'taboo' derives from the Tongan tabu, discovered by Captain James Cook on 15 June 1777 in Polynesia on his first voyage to Tahiti (Allan \& Burridge, 2006:3; Freud, 1913/2004: 21). Broadly, taboo associated with certain activities that can be served as a means of social control. From this matter, it is suggested that taboo belongs to a part of cultural norms to be obeyed in order to avoid undesirable events. Meanwhile, Kridalaksana (1982: 161) provides two definitions of taboo, namely: (1) which is forbidden, both because of a harmful force (positive taboo) and because of the power that contaminates or destroys one's life force (negative taboo) avoided by using euphemism; (2) the prohibition of using certain words, for fear or for the sake of politeness; for instance, people do not call 'the dead' in front of the dead person. 


\section{METHOD}

Qualitative approach is used to describe in depth the phenomenon of communication which violates the karonese culture. In doing the research, the researcher applied some ethnographic methods proposed by spradley (1980).

\subsection{Population}

Arikunto (2002:108) Satates:” A Population is all of research subject. If a people want to research area, so this reseach is population research. Study of this research called population study".

Everything that can make as research object or as a place to get that data research needs. The population of this research is peoples karonese of live at langkat. This location of conducting research is taken in "Jambur" (the place where the mourning tradition). In order to make the process of collecting data becomes easier, a table will be created to arrange the euphemism words. The data will be identified base on the words. Phrases and which consist of euphemism by typing them into a note. After the data found, they will be analyzed based on the context and function. The data of this research are the words, phrases and clauses contain euphemism.

\subsection{Sample}

Sample is a part of population that looked from the represent the population becomes as source of the data or source of information in a research. As the sample of this research, the writer took one environment at langkat. There are some ways and steps in getting the information. This research will be conducted at Langkat choosing this place as the location. The study uses a qualitative descriptive approach, to describe the data carefully, the source of data will be taken from interview in people karonese at villange bahorok, langkat and taken from some journal's books and some informen karonese culture who knows this mourning karonese's tradition well.

\subsection{Data Collection}

This research was conducted in karo District, Sumatera Utara Provience, Indonesia, which is inhabited by most karo people. The data sought in this study are data of language and data of speaking. Data of languages is in the form of karo words of phrases that contain literally,forexample : As Verb :'to'ente'ndi'ena'nta'endo'gule'tasak'medem'tayang'napui'

Merawa'jungut-jungut'dilo'ente'diloken'tangis'ngandung'mari'eko.etc.Which were obtained from the old native informants through in-depth interviews, and data of speaking in the form of verb, noun, adjective words expression collected through participants-observation method.

\subsection{Data Analysis}

In analyzing data used to karonese euphemism word and karonese (impolite) taboo harsh words. The researcher uses the name of "language taboo" or euphemism in karonese language. In order words, this stage of analysis was an attempt to explore the meaning contained in the symbols of the existing language. This reseach will give a value, norms or local wisdom in karonese community. Euphemism in karonese langkat is not only for the words, but also in some phrases.

\section{FINDING \& DISCUSSION}

\subsection{Finding}

Based on my observation and interview the data taken from the respondents show that euphemism used in Karonese language divided in some categories such pronoun, adjective, verb, and noun. The use of Euphemism in Karonese language is not only for the words, but also in some phrases. The researcher uses the name of "language taboo" when referring to words, phrases, expressions, etc. The following tables present the study's results: 
Table 1. Euphemism word in karonese language as pronoun.

\begin{tabular}{ccccc}
\hline No. & $\begin{array}{c}\text { Karonese } \\
\text { Euphemish word }\end{array}$ & $\begin{array}{c}\text { Karonese } \\
\text { Taboo/Harsh word }\end{array}$ & English & Term of Reference \\
\hline 1. & Kam & Engko & You & Noun \\
\hline 2. & $\mathrm{Ndu}$ & $\mathrm{Mu}$ & Your & Possesive Pronoun \\
\hline 3. & $\mathrm{Ta}$ & $\mathrm{Ku}$ & Our & Possesive Pronoun \\
\hline 4. & $\mathrm{Kena}$ & Kalak & They & Noun \\
\hline 5. & $\mathrm{Ndi}$ & $\mathrm{Nah}$ & It's & Possesive Pronoun
\end{tabular}

This table explain about euphemism word in karonese language as pronoun.

Example in sentence :

Euphemish in Karonese language

1. Tendingku

2. Pulpen $n d u$

3. Kena ngo man

4. Ndi kibul bolana

5. Ta lawes kujoh

English
my soul
your pen
they have eaten
it's round theball
we go there

The use of second person singular you, "kam" in polite linguistic. It is second pronoun regarded as an obvious sign of polite. Another polite pronoun "ndu" is the possessive singular second person. The first person is in common use " $\mathrm{i}, \mathrm{my}$, mine" aku, ku, ta: the second person is in general use "you, your, yours" (engko, kam, mu, ndu). Karonese language has culture to reveal polite or impolite culture. Karonese is known as an ethnic group of the etiquett.

Table 2. Euphemism in karonese language as verb

\begin{tabular}{cccc}
\hline No. & $\begin{array}{c}\text { Karonese euphemism } \\
\text { word }\end{array}$ & $\begin{array}{c}\text { Karonese } \\
\text { taboo/harsh word }\end{array}$ & English \\
\hline 1. & To & Ente & Go \\
\hline 2. & Ndi & Enah & Here \\
\hline 3. & Nta & Endo & Give \\
\hline 4. & Mari & Eko & Come on \\
\hline 5. & Gule & Tasak & Cook \\
\hline 6. & Napui & Napu & Broom \\
\hline 7. & Dilo & Ente diloken & Call \\
\hline
\end{tabular}

Table 3. Euphemish in karonese language as noun

\begin{tabular}{cccc}
\hline No & $\begin{array}{c}\text { Karonese euphemism } \\
\text { word }\end{array}$ & $\begin{array}{c}\text { Karonese taboo/ } \\
\text { harsh word }\end{array}$ & English \\
\hline 1. & Jelma & Kalak (orang) & People \\
2. & Labah & Labah & Door \\
3. & Biang & Bengkala & Dog \\
4. & Manuk & Manok & Cock \\
5. & Lau & Lau & Water \\
\hline
\end{tabular}


Table 4. Euphemism in karonese language as adjective

\begin{tabular}{cccc}
\hline No. & $\begin{array}{c}\text { Karonese euphemism } \\
\text { word }\end{array}$ & $\begin{array}{c}\text { Karonese taboo/ } \\
\text { harsh word }\end{array}$ & English \\
\hline 1. & Gutul & Cilaka & Naughty \\
2. & Nokoh & Nokoh & Lie \\
3. & Mehuli & Merandal & Good \\
4. & Adon & Mehado & Crazy \\
5. & Ngandung & Tangis & Crying \\
\hline
\end{tabular}

\subsection{Discussion}

To the researcher's knowledge, there has no studied about taboo in Karonese language that provides detailed information so far. Taboo study will not provide complete information if the study is based on lexical meaning only. Since taboo is a culture norm, it must be explored in the context of its usage. The taboo rule actually provides specific way to avoid it in communication, Karo is one of cultured tribes in the world which has strict norms in maintaining the relationships within its community. From the result shows that, As we know that use of euphemism in Karonese language more dominant for using pronoun in daily conversation. The word chosen also to describe the speaker character and influence with whom we talk. While in this culture are highly ethical between attitude and speech, in oral speech karonese analyzed and classified by the classification according. For example when we talk with oldest we should consider the euphemism word "kataken" ngata to respect them. In Karonese language people tend to use of euphemism as consideration to adapt speech in different addressee and situation, and show respect and politeness each other.

\section{CONCLUSION}

It can be concluded that Euphemish in karonese language langkat, there are some euphemism word in karonese language more dominant for using pronoun in daily conversation. The use of euphemism in karonese language divided in some categories such pronoun, adjective, verb and noun. In here euphemism in karonese language is not only for the word, but also in some phrases. As the educational function because we can take many learning about this tradition such as in motivating, advising, and amusing condolences people, so they will not feel lonely and be stronger to face the sorrow.

Besides that, the researcher suggests to the society members of bahorok village in langkat district are able to apply more and add the intensity to use karonese language in the langkat and It is hoped give the new generation will not forget the importance of this tradition and easier them to find out about in the mourning tradition of Karonese. And Base on my Observation, at apply in target language, or in the source language.

\section{REFERENCES}

Allan, Keith and Burridge, Keith. (2006). Forbidden Words: Taboo and the Cencoring of Language. New York: Cambridge University Press

Rawson, H. 1981. A Dictionary of Euphemisms and other Double-talk. New York: Crown Publishers.

Holder, R.W. (2002). How Not to Say What You Mean: A dictionary of Euphemisms. Oxford University Press.

Ji-gang, YAO. 2005. "A Comparative Study of English Euphemism and Chinese Euphemism". Journal of Suzhou Education Institute, 5/2005, pp. 115 - 122. Available at http://www.ccpcc.com/jjxj/km1/020642.htm.

Bisel, R. S., Kelley, K. M., Ploeger, N. A., \& Messersmith, J. (2011). Workers' moral mum effect: On facework and unethical behavior in the workplace. Communication Studies, 62, 153170. doi: 10.1080/10510974.2010.551314 
Bisel, R. S., Messersmith, A. S., \& Kelley, K. M. (2012). Supervisorsubordinate communication: Hierarchical mum effect meets

NODEX = The New Explanatory Dictionary of the Romanian Language, Litera International Publishing House, 2002.

Khalma, E. (2013). Bentuk Nuri-nuri Pada Upacara Adat Kematian Suku Karo.

BROWN, Penelope, and Stephen C. LEVINSON (1987).Politeness: Some Universals in Language Usage.Cambridge: Cambridge University Press.

Ginting, R. (2009). Nilai dan Fungsi Ndundugen Karo. Journal of the Mourning Tradition of Karonese. Page 1-5.

Sembiring, Milisi. (2013). Translating Rebu in Karonese Society into English. Dalam IOSR Journal Of Humanities And Social Science (IOSR-JHSS) Volume 17, Issue 1 (Nov. - Dec. 2013), PP 30-36 e-ISSN: 2279-0837, p-ISSN: 2279-0845.

Sembiring, M. (2016). Translating Politeness of Maba Manok Mbor Texts in Karonese Society into English.

Surbakti, H. (2015). Translation techniques of tradition Karonese Medical text on fractured bone setting.

Ginting, Y. \& Rahmah (2014). The logical function is simate-mate (the nouring Tradition of Karonese Culture)

Mocanu, M. (2016). Taboo and Euphemism in the religius language" in: Journal Internasional letters of social and humanistics Sciencies.

Yusmaniar, A., Lubis, H. H., Simorangkir, S., \& Surbakti, B. (1984). Struktur Bahasa Karo.

Mocane, M. (2016). Taboo and Euphemism in the Religious Language.

Barus, J., Sibarani, R., Saragih, A., \& Mulyadi. (2018). Linguistic Taboo in Karonese Culture.

Rosa, R. N. (2014). Types and Form of Euphemism Used in Minangkabause.

Boangmanalu, I. A., \& Lumbangao, G. (2014). Penggunaan Kata Maaf dan Terimakasih : Kesantunan Berbahasa Bahasa Batak Toba. Pascasarjana Universitas Sebelas Maret.

http://www.Karo.or.id//gendang-kematian-dan-kematian-gendang-pada-masyarakat karo)Accessed at 14 th January 2014.

http://www.silima -merga.blogspot.com. Accessed 14th January 2014. 